\title{
13 A Natural Experiment on Innovation Without Patents
}

\author{
Andrew W. Torrance
}

\subsection{Introduction}

Innovation occurs within a complex web of law. Of the myriad legal doctrines that affect innovation, the most directly relevant is intellectual property, particularly patent law. The United States Constitution, in Article I, Section 8, states a strong public policy goal for the granting of patents (and copyrights) to inventors: "To promote the Progress of Science and useful Arts, by securing for limited Times to Authors and Inventors the exclusive Right to their respective Writings and Discoveries.” Despite the Founding Fathers' apparent faith in the societal benefits afforded by patent protection, a crescendo of recent critics have accused the patent system of complicating, slowing, or even thwarting innovation (von Hippel 2005, Benkler 2006, Bessen and Meurer 2006, Jaffe and Lerner 2006, Boldrin and Levine 2008, Torrance and Tomlinson 2009, Burk and Lemley 2009, Torrance and Tomlinson 2011). Patents certainly present significant hurdles for open and user innovation. Moreover, von Hippel (2005) and Strandburg (2008) have demonstrated that user innovators, especially individuals, tend to be poorly served, and often harmed, by the patent system. 
Empirical evidence evaluating how well the patent system achieves its stated goals of encouraging innovation is notably scarce (Torrance and Tomlinson 2009, Torrance and Tomlinson 2011). Even the U.S. Congress, in Section 30 of the America Invents Act of 2011 (“AIA”), has voiced its anxiety that patents may sometimes impede innovation, urging the need "[to protect] the rights of small business and inventors from predatory behavior that could result in the cutting off of innovation.” Although some have called for the abolition of patent protection (Boldrin and Levine 2008), commitment to the patent system remains strong among U.S. policymakers, as evidenced by the recent passage of the AIA, and has been a treaty obligation since the U.S. ratified the World Trade Organization Agreement on Trade-Related Aspects of Intellectual Property ("WTO-TRIPS”) in 1995. Thus, the U.S. is likely to maintain a patent system for the foreseeable future. However, one section in the AIA - Section 33 - may offer a rare and valuable opportunity to explore how innovation, especially open and user innovation, might perform without the protections or constraints of patents.

When President Barack Obama signed the AIA into law on September 16, 2011, he formally created, within the field of biotechnology, an exception to patentable subject matter. His predecessor, President George W. Bush, had called on Congress, in his 2008 State of the Union address, "to pass legislation that bans unethical practices, such as the ... patenting ... of human life.” Section 33 of the AIA states that "[n]otwithstanding any other provision of law, no patent may 
issue on a claim directed to or encompassing a human organism.” Section 33 took full legal effect on September 16, 2011, but did not retroactively invalidate patents already in force. Although patents claiming inventions "directed to or encompassing” aspects of human organisms, such as human bodies, organs, tissues, cells, genes, chemical products of physiological processes, and even thoughts have often been granted by the United States Patent and Trademark Office (“USPTO”), patents claiming this class of biotechnological inventions have proved increasingly difficult successfully to assert in court (Torrance 2008, 2009, 2010a, 2013). It is too early to know precisely how the United States Patent and Trademark Office (“USPTO”) and the courts will interpret Section 33. Nevertheless, a rich body of judicial decisions on the validity, enforcement, and infringement of patents claiming human genes, human embryonic stem cells ("hESCs"), chemicals produced by human physiology, and human thought (especially relating to diagnosis and therapy) do provide valuable insight into how far Section 33 may reach. These decisions suggest that inventions related to the human body and its functions represent a lacuna in patentable subject matter. If interpreted in a manner consistent with this body of court decisions, Section 33 may represent an apotheosis of the marked common law trend against the patenting of inventions relating to the humans, the human body, and human bodily processes. 
Exceptions to patentable subject matter have rarely been formally incorporated into the Patent Act. With the addition of Section 33 to the patent law, both statute and judicial precedent have now created a space in which innovation “directed to or encompassing a human organism” may take place substantially unfettered from fears of infringing new patent rights. This safe harbor from patent infringement, though circumscribed by the limits of Section 33, allows a natural experiment to take place in which innovation may operate without interference from new patent rights. Far from a desire to foster user and open innovation in human-related biotechnology, the primary rationale for this amendment to the Patent Act was strong repugnance to biological research leading to, and the possibility of resultant ownership interests in, inventions involving human beings. Rather, it is incidental that this natural experiment may provide valuable insight into how patents affect innovation, especially user and open innovation. Under these rare conditions of freedom from patents, innovation, especially user and open innovation, may flourish.

Strictly controlled access to biological laboratories and the specter of legal liability, especially that related to biosafety and intellectual property rights, have combined to discourage open and user innovation in biotechnology (Torrance 2010b). Nevertheless, even prior to the patent-safe harbor created by Section 33, biotechnology had already begun to migrate out of the professional laboratory, and into the realm of open and user innovation. Detailed protocols for carrying 
out molecular biological techniques have long been accessible on the internet. Both prices and availability of machines, apparatus, chemical reagents, and biological materials required in biotechnology have improved markedly, a trend accelerated by the outsourcing of services such as gene sequencing and synthesis and the rise of biotech company bankruptcies during the economic downturn that began in 2008. Furthermore, the BioBricks Foundation has assembled, and makes widely available, a vast and growing collection of well-characterized Lego-like genetic building blocks (the eponymous "BioBricks”) catalogued in its Registry of Standard Biological Parts. The International Genetically Engineered Machine (“iGEM”) Foundation has dramatically increased undergraduate, and even high school, student participation in synthetic biology worldwide through the annual iGEM competition, which is held at the Massachusetts Institute of Technology and involves the construction of genetically-engineered organisms and systems built with BioBricks (Torrance 2010b, Torrance and Kahl 2014). At the grassroots level, do-it-yourself biology (“DIY Bio”) organizations, such as BioCurious, have formed to democratize access to biological knowledge and practice by providing common laboratory space and expertise sharing to anyone interested in learning and doing biotechnology.

Formerly, such endeavors were the exclusive domains of large and wellfunded university, government, institution, and commercial laboratories accessible almost exclusively to those having formal scientific credentials, such as 
doctorates. If Section 33 were to lead to even greater amounts of user and open innovation in human-related biotechnology, this patent-safe harbor could provide a model for further patent reform creating additional patent-safe harbors in other fields of technology. A negative effect on innovation would provide evidence supporting the traditional assumption that patents spur relatively more innovation. No significant change in overall innovation rate is yet another possible outcome. Such a result might align with earlier empirical comparison of innovation rates across countries with and without patent systems, in innovation rates were observed to have remained relatively stable with or without patent protection, while protection by trade secrecy rose markedly in systems without patents (Moser 2005). Regardless of which of these patterns is observed, the legal change heralded by Section 33 provides a rare and valuable insight into how to craft patent policy that successfully promotes innovation.

This chapter introduces the broad contours of the U.S. patent system, including some of the major reforms made to patent law by the AIA. It discusses the unease with which the law of property and intellectual property apply to human beings. Next, it explores the reluctances courts have shown towards the patentability of inventions directed to human beings: specifically, human genes, hESCs, chemical products of human physiological processes, and human thought (especially methods of diagnosis and treatment). The chapter concludes by suggesting that Section 33 offers a rare opportunity to observe a natural 
experiment in which innovation may operate unconstrained by patents, and that the results of this experiment may provide a model for future reform of the patent system to the benefit of innovation, especially open and user innovation.

\subsection{The Patent System}

The U.S. patent system differs in a number of respects from the patent systems that predominate in other countries. The current system rewards the first person to invent with a patent, rather than the first person to file a patent application. In addition, the U.S. patent system is more likely to consider personal, noncommercial, educational, and research uses to be infringing than would many other countries.

\subsubsection{Patent Requirements}

To qualify for a patent, an invention must meet several legal requirements set out in the Patent Act. An invention must fall within acceptable categories of subject matter, be useful, new (both literally new and nonobvious), and adequately described in a patent application. Furthermore, the metes and bounds of any aspects of the invention its inventor wishes to protect must be carefully defined in the stylized form of patent claims. If a patent applicant can demonstrate to the USPTO that her patent application satisfies all of these requirements, in addition 
to a number of formalities, the USPTO will issue a patent whose claims describe the monopoly rights to exclude others conferred on the patent owner.

\subsubsection{Patentable Subject Matter}

Section 101 of the Patent Act enumerates several categories of inventions eligible for patent protection. These are "any new and useful process, machine, manufacture, or composition of matter, or any new and useful improvement thereof". In 1980, when the United States Supreme Court decided the patent case Diamond v. Chakrabarty, it famously ratified a Congressional Committee Report that had interpreted Section 101 as including "anything under the sun that is made by man.” Nonetheless, the Court was careful to highlight the unpatentability of "laws of nature, physical phenomena, and abstract ideas.” In interpreting these exceptions to patentable subject matter, the courts have only limited the patenteligibility of a small number of other categories of inventions. One class of technology to which courts have paid particular attention involves inventions that implicate a human organism, human body, or substituents body parts or processes; courts have tended to place these inventions towards the unpatentable end of the patentability spectrum. Section 33 is likely to reinforce the unpatentability of such inventions. 


\subsubsection{The Right to Exclude Others}

Once a patent has been issued by the USPTO, Section 271 of the Patent Act allows a patent owner to exclude others from making, using, selling, offering to sell, or importing any inventions it claims. This negative monopoly right to exclude others can be powerful because it is based on the legal theory of strict liability. Under strict liability, knowledge and intent tend to be relatively unimportant compared to occurrence of an infringing act. Even independent invention tends not to be a defense to patent infringement. Consequently, a patent owner may successfully sue anyone who infringes a patent claim, whether or not such infringement is knowing, unknowing, deliberate, accidental, commercial, noncommercial, or even for educational, research, or personal use. This relatively unforgiving standard of liability contrasts with the more lenient treatment for noncommercial, educational, research, and personal use that tends to prevail under the patent laws of other countries. With rare exceptions (for example, experimentation necessary to achieve regulatory approval for a generic version of a patented pharmaceutical drug), liability for patent infringement hinges on proof of infringing acts.

The law of patent infringement applies with full force to open innovation and user innovators, whether individuals or firms. The costs involved in patent lawsuits tend to be prohibitively expensive, with patent litigation costs often exceeding \$3 million (Torrance 2007). Because firms usually possess relatively 
greater financial resources than do individuals to mount the expensive legal efforts necessary to defend themselves against patent infringement lawsuits, it is individuals, such as user innovators, who are most at risk of catastrophic outcomes when sued by patent owners. The mere risk of being sued for patent infringement can chill user innovation. Locating patents that one might infringe is challenging. Furthermore, patent claims are often devilishly difficult to interpret prior to expensive litigation (Bessen and Meurer 2008), making it challenging for potential infringers to know a priori how to order their behavior to avoid infringement.

Even if it is necessary to practice the claims of a patent in order to improve a claimed invention, practicing the claims even for this socially useful purpose can trigger infringement. Similarly, practicing patent claims for purely personal and noncommercial purposes may still result in liability for infringement. Open and user innovators possess no special privileges that allow them to escape liability for patent infringement. Under such conditions, there is likely to be a substantial chill on open and user innovation, as those involved in such kinds of innovation weigh the benefits of inventing against the potential threat of infringement litigation. Even though larger commercial entities with greater access to financial resources are much more likely to be sued for patent infringement, smaller parties, such as user innovators, may still fear the unlikely, 
yet catastrophic, possibility of having to defend themselves against infringement allegations.

\subsubsection{The America Invents Act of 2011}

For years, there have been efforts in Congress to bring comprehensive reform to the patent statutes. Since their last great reformulation, in 1952, numerous piecemeal amendments have been made to the patent statutes. For example, in response to the WTO-TRIPs, the U.S. amended the Patent Act in 1995 to provide patent owners with 20 years of potential patent protection from first filing date instead of the previous 17 years of patent term from patent issuance. Despite a steady drumbeat of individual amendments to the patent statutes, momentum for major patent reform grew over the past decade, and culminated with passage of the AIA.

The AIA includes many changes to U.S. patent law, some of which will help to harmonize American patent law with practice in the rest of the world. Some of these changes may even benefit user innovators. Under amended Section 102 of the patent statutes, there is a new first-inventor-to-file rule to encourage inventors to file patent applications as soon as inventions are completed, as only the first inventor who files a patent application claiming an invention will be eligible for a patent. Section 102 also institutes a new absolute novelty standard under which an inventor risks complete loss of patent rights if any third party 
discloses the inventor's invention prior to the filing of a patent application. One beneficial implication of this reform may be to place detailed information about new inventions into the possession of the public earlier, which could encourage follow-on innovation.

Another substantial change to current patent law involves the creation of a post-grant review procedure (Sections 321-330), a new and potentially powerful means for challenging the validity of newly-granted patents. Like the patent opposition system already in place in Europe, post-grant review will create a formal administrative proceeding in the USPTO that anyone may use to challenge patents. Post-grant review will be much more rapid and less expensive than litigation in court. In addition, new Section 273 offers a defense to patent infringement for commercial use of a patented invention that began prior to the filing of a patent application or public disclosure by the patent owner. As discussed above, the new patent reforms also include a notable subject matter exclusion in biotechnology in the form of Section 33.

Each of these amendments will affect user innovators. Although the actual effects of these provisions may not be understood until courts begin to interpret the AIA, user innovation should benefit from the early elimination of poor quality patents, acceleration in patent application filings (and concomitant acceleration in patent expirations), availability of a prior commercial use defense, and creation of a patent-safe harbor for certain types of biotechnology. 


\subsection{Patents on Human Beings}

The possibility that a patent could claim a human being, either in whole or in part, is repugnant to many people. There exists a widely shared opinion that humans must not be treated as property - even intellectual property - under the law. Patents that claim mere parts of a human, such as genes, may inspire "the visceral fear of corporate interests claiming ownership over our very bodies” (Crease and Schlich 2003). The law is clear that human beings cannot constitute property. The Thirteenth Amendment of the U.S. Constitution prohibits property interests in humans. Nor can human beings be intellectual property. In its 1987 Policy Statement on Patentability of Animals, the USPTO announced that " $[\mathrm{t}]$ he grant of a limited, but exclusive property right in a human being is prohibited by the Constitution.” The issue of patenting humans has even reached the highest levels of political discussion. President George W. Bush used his final State of the Union address on January 29, 2008, to exhort “Congress to pass legislation to ban unethical practices such as the ... patenting ... of human life.” Inventions directed to or encompassing human beings, their bodies, or the parts or processes thereof, do not fit well within either property or intellectual property. 


\subsubsection{Humans as Property}

Anglo-American law forbids the ownership of human beings or their bodies. Just as people cannot constitute property according to the Thirteenth Amendment of the U.S. Constitution, the common law has long prohibited human bodies from constituting property (Madoff 2009). Markets in human body parts have also tended to be illegal, whether those body parts derived from living human beings (Rao 2007) or dead human bodies (Goodwin 2006). Similarly, intellectual property protection for inventions that encompass aspects of humans and their bodies is difficult to obtain, and even more difficult to enforce in court.

Experimentation involving human beings has profound ethical and moral implications for most people. Patent law provides only one set of legal constraints on such activity: the ability to exclude others from practicing a claimed invention. Criminal, health, tort, family, and abortion law all offer more direct and robust regulation of the uses and abuses of humans at various developmental stages. Thus, despite Congress' legislative action on the issue of patentability, other areas of law, morality, and ethics are likely to play more decisive roles in regulating human-related inventions.

\subsubsection{Humans as Intellectual Property}

Many inventions incorporate human participation, or involve substituent parts of humans, such as genes, proteins, cells, tissues, or organs. Some patents, such as 
U.S. Patent No. 6,200,806 (“Primate Embryonic Stem Cells”), even claim cells having the potential to develop into entire human beings. The USPTO and the European Patent Office (“EPO”) have long granted patents claiming such human subject matter. However, whatever administrative agencies, such as patent offices, may grant, courts and legislatures may take away.

Until the passage of Section 33, patents on human-related inventions were formally constrained by an ad hoc assemblage of Congressional riders, judicial opinions, USPTO policies, and presidential statements regarding the patenting of human beings, human body parts, and human bodily processes. A few examples may serve to illustrate this piecemeal regulation. In the 1972 case, Gottschalk v. Benson, the Supreme Court barred patentability of any process made up of “purely human thought.” Section 287 of the patent statute limits liability for patent infringement of methods of surgery by medical personnel and medical facilities. The USPTO has declared human-nonhuman genetic hybrids, or chimaeras, unpatentable. Since 2004, the "Weldon Amendment” Congressional rider was repeated renewed by each new Congress, ensuring that "[n]one of the funds appropriated or otherwise made available under this Act may be used to issue patents on claims directed to or encompassing a human organism.” The USPTO Manual of Patent Examining Procedure (“MPEP”) specifically states at $\S 2105$ that, "[i]f the broadest reasonable interpretation of the claimed invention as a whole encompasses a human being, then a rejection under 35 U.S.C. 101 must 
be made indicating that the claimed invention is directed to nonstatutory subject matter.” And, in 2000, President Bill Clinton and Prime Minister Tony Blair together publicly urged the biotechnology industry not to seek patents claiming human genes.

However, even though the patent statute lacked any definitive prohibition regarding the patenting of human-related inventions prior to Section 33, the courts have successfully limited the patentability of human genes, hESCs, products of in vivo conversion, and human thought. This judicial regulation of patents claiming human-related inventions possesses considerable value in providing guidance for the interpreting of Section 33.

\subsection{Patents Directed to or Encompassing Human Beings}

Patents on four categories of human-related biotechnological inventions have attracted considerable attention in the courts: human genes, hESCs, chemical products of in vivo conversion, and methods involving elements of human thought. Each of these categories fits comfortably within the codified provisions of the pre-AIA patent statute, as interpreted by the Supreme Court. Nevertheless, lower courts, the federal executive branch of government, and Congress have all contributed to a trend whose direction has been the increasing curtailment of patent rights covering human-related inventions. 


\subsubsection{Patents Claiming Human Genes}

According to Fiona Murray and Kyle Jensen (2005), approximately 20\% of the known genes in the human genome have been claimed in patents issued by the United States Patent and Trademark Office. Allowing such a patent gold rush has been challenged on ethical grounds (Hollon 2000). Heller and Eisenberg (1998) have warned that excessive patenting of genes could result in a tragedy of the anticommons for genetic research. Michael Crichton (2007) expressed the more extreme fears of the public when he wrote in the New York Times, "YOU, or someone you love, may die because of a gene patent. ... Gene patents are now used to halt research, prevent medical testing and keep vital information from you and your doctor.” In short, the patenting of DNA has captured the attention of the public, politicians, and judges over the last decade. The result has been an increasingly unfavorable climate for patents claiming human genes, with judicial decisions making their contribution by curtailing patent rights in genes.

In 2005, the Court of Appeals for the Federal Circuit (“CAFC”) decided the In re Fisher appeal. This case concerned whether patent claims to certain partial sequences of genes, called “ESTs” or "expressed sequence tags,” possessed the requisite utility and enabling disclosure. The CAFC ruled that these claims to gene fragments were invalid, and thereby cast doubt on the patentability of EST gene fragments. In 2007, two members of the House of Representatives, Xavier Becerra (Democrat of California) and Dave Weldon (Republican of 
Florida), proposed the Genomic Research and Accessibility Act. Section 106 would have required that "[n]otwithstanding any other provision of law, no patent may be obtained for a nucleotide sequence, or its functions or correlations, or the naturally occurring products it specifies.” This proposed statutory amendment would have eliminated gene patents - whether derived from humans or other organisms - from U.S. law. Though Congress has never passed this bill, it did hold hearings into the issue of gene patents in late 2007.

In 2009, the American Civil Liberties Union (“ACLU”) represented several female patients and supporting organizations in suing to end gene patents and genetic methods of diagnosis. The plaintiffs sued the USPTO on the grounds that issuing gene patents was impermissible. In addition, they sued a Utah-based biotechnology firm, Myriad Genetics, and the Directors of the University of Utah Research Foundation, seeking to invalidate their gene patents, which claimed, among other inventions, the BRCA1 and BRCA2 gene mutations useful in predicting the risk of developing breast and ovarian cancer. As the plaintiff's complaint argued,

Every person's body contains human genes, passed down to each individual from his or her parents. These genes determine, in part, the structure and function of every human body. This case 
challenges the legality and constitutionality of granting patents over this most basic element of every person’s individuality.

To the surprise of many, the district court sided decisively with ACLU, holding that neither human genes nor genetic tests that relied on human genes constituted eligible subject matter for patent protection. Instead, Judge Sweet argued that genes "containing sequences found in nature ... are deemed unpatentable subject matter.” The plaintiffs filed an appeal with the CAFC. In October 2010, the United States, a defendant in the case by way of the USPTO, confused both the plaintiffs and its fellow defendants by filing an amicus curiae brief with the CAFC taking the position that "isolated but otherwise unaltered" human genes should be considered unpatentable under the law. In July 2011, a panel of three CAFC judges reversed much of Judge Sweet's decision, in AMP v. Myriad Genetics, and reaffirmed the patent-eligibility of human genes. However, the legal pendulum swung back on March 26, 2012, when the Supreme Court vacated AMP v. Myriad Genetics, and ordered the lower court to reconsider the patentability of human genes in light of Mayo v. Prometheus, a case the Supreme Court had decided a week earlier. In Mayo v. Prometheus (discussed further below), the court unanimously held methods of using human metabolites in diagnosis and therapy to constitute unpatentable subject matter. By vacating AMP v. Myriad Genetics, and demanding a new decision consistent with Mayo v. Prometheus, the 
Supreme Court cast considerable doubt on the patentability of human genes. This doubt was dispelled on June 13, 2013, when the Supreme Court unanimously decided AMP v. Myriad, invalidating Myriad's patent claims covering isolated human genomic DNA, though it also suggested that at least some synthetic DNA remained patent-eligible subject matter.

\subsubsection{Human Embryonic Stem Cells}

In 1998, the University of Wisconsin Alumni Research Foundation (“WARF”) filed the first in a series of patent applications claiming hESCs, methods of producing them, and their various uses in therapeutic and other applications (Rimmer 2008). These patent applications were based on foundational research by Dr. James Thomson and his research group that took place at the University of Wisconsin. Thomson and his colleagues were the first to identify and culture pluripotent hESCs. Then Commissioner of the USPTO, Todd Dickenson, addressed the Congressional Subcommittee on Labor, Health and Human Services, Education and Related Agencies of the Senate Appropriations Committee in 1999 to clarify that hESCs could indeed constitute patentable subject matter under existing patent law. The first patent resulting from the research of the Thomson laboratory issued as U.S. Patent Number 6,200,806 ("Primate Embryonic Stem Cells") in March 2001. It claimed both methods of isolating hESCs and all five hESC cell lines themselves. Several other related 
hESC patents would later issue based on research carried out by Thomson and his team of researchers.

The WARF patents were licensed to Geron Corporation, a biotechnology firm specializing in the development of regenerative medicine products and therapeutic methods. Opponents of patents claiming hESCs, including the Public Patent Foundation, challenged the WARF patents using a USPTO procedure called a reexamination. In the first round of reexaminations, three major WARF patents were found to be invalid. To salvage these patents, WARF was forced to amend and narrow the coverage of these patents' claims. These amendments marked a retreat away from claiming later stages of embryonic development (e.g., "post-implantation embryonic germ cells") and towards claiming much earlierstage cells (e.g., derived from a "pre-implantation embryo" or "human blastocyst”) and "in vitro cell cultures" not derived from human embryos. In effect, these amendments distanced the patent claims from human embryos per se or even later stages of embryonic development. After additional rounds of reexamination, resulting in more amendments that further narrowed the scopes of the claims, the surviving patents emerged from reexamination without claims that could cover totipotent hESCs capable of producing a human being. Given the ethical controversies surrounding hESCs, it is likely that these WARF patents, and other patents claiming hESCs, will continue to face patentability challenges to 
the extent that their claims implicate human beings or methods of producing them.

European patent law has tended to limit patents on hESCs more explicitly than U.S. patent law. For example, the same WARF patents whose claims have been substantially narrowed in reexamination in the USPTO have been found invalid in Europe. Articles 5 and 6 of the 1998 European Union Directive on the Legal Protection of Biotechnological Inventions offer a number of grounds for prohibiting patenting inventions involving hESCs. In its 2002 Opinion on the Ethical Aspects of Patenting Inventions Involving Human Embryonic Stem Cells, the European Commission's European Group on Ethics in Science and New Technologies warned that "such isolated cells are so close to the human body, to the foetus or to the embryo they have been isolated from that their patenting may be considered as a form of commercialization of the human body.” Furthermore, Rule 29(1) of the Implementing Regulations to the Convention on the Grant of European Patents warns that "[t]he human body, at the various stages of its formation and development, and the simple discovery of one of its elements ... cannot constitute patentable inventions.” Finally, on October 18, 2011, the Court of Justice of the European Union decided the case of Oliver Brüstle v. Greenpeace e.V., holding unpatentable any inventions that "require the prior destruction of human embryos or their use as base material, whatever the stage at which that takes place.” Thus, based on these various legal authorities, many 
aspects of hESCs are unpatentable in the European Union. Now that Section 33 is law, both the U.S. and European patent systems share considerable similarities in their treatment of patents claiming inventions related to hESCs.

\subsubsection{Chemical Products of Human Physiology}

The human body routinely converts ingested or injected chemicals into different chemical products through physiological processes. This process is called in vivo conversion because the chemical transformation of precursor chemicals, or “prodrugs,” into physiological products, or “drugs,” takes place within the living human body. Drugs produced from prodrugs through in vivo conversion are sometimes therapeutically effective (Silverman 2004). Consequently, patent applicants have routinely sought patent protection to cover products of in vivo conversion, or the uses thereof, and the USPTO has granted many patents that claim products or processes of in vivo conversion. However, patent claims whose elements involve physiological processes that occur within the human body have consistently fared poorly in court. Overwhelmingly, U.S. courts of final appeal do not find patents claiming products of in vivo conversion to be valid, enforceable, and infringed (Torrance 2008).

Courts deciding in vivo conversion patent cases have offered a variety of rationales to justify this consensus outcome. These have pointed to the difficulties of securing evidence inside a living human body, invoked inherency, and made 
distinctions between "natural" and "synthetic" drugs and chemical changes that occur inside versus outside the human body. Despite this diversity of rationales, what links these outcomes together is the apparent discomfort courts have had in enforcing patents that claim products or processes that originate from physiological processes of the human body. Torrance (2009) has ascribed the unanimous result of such patent cases to the existence in the law of a “physiological steps doctrine.” In 2012, the Supreme Court finally decided a case, Mayo v. Prometheus, involving inventions related to human metabolites, and unanimously held these inventions to constitute unpatentable subject matter.

As in the case of hESCs, European patent law is more explicit in setting limits on the patentability of inventions relating to therapy. The European Patent Convention (EPC) Article 52(4) prohibits patents covering "methods for treatment of the human or animal body by surgery or therapy and diagnostic methods practised on the human or animal body.” Although, Article 52(4) recognizes an exception for "products," drugs whose therapeutic effects are produced through in vivo conversion have fared poorly under European patent law, just as they have under U.S. patent law.

\subsubsection{Human Thought}

Although lacking the obvious physical embodiment possessed by a human gene, hESC, or metabolite, human thought is still a product of the human body, 
specifically neurological processes within the brain. Like patents claiming genes, hESCs, and metabolites, patents claiming aspects of human thought have experienced much resistance from U.S. courts. In a 1951 case, In re Abrams, the United States Court of Customs and Patent Appeals (the predecessor of the CAFC) declared that "[i]t is self-evident that thought is not patentable." Inventions with methods including elements of human thought are often held unpatentable by courts under the "mental steps doctrine.” In its 1972 decision, Gottschalkv. Benson, the Supreme Court declared that an invention must be considered unpatentable if its claimed elements are composed of "purely mental steps." Human thought itself is closely associated with the human body, especially the brain. More precisely, thought results, at least in part, from neural pathways made up of neuronal cells (Purves et al. 2008). This close association with the human body provides a modern scientific rationale for the mental steps doctrine (Torrance 2009), and provides a linkage between thought patents to patents claiming other human-related inventions.

In recent years, there have been several influential court decisions regarding the patentability of inventions involving human thought, particularly methods of human diagnosis that include mental steps as claim elements. In 2006, the Supreme Court agreed to hear the appeal of Laboratory Corporation of America Holdings v. Metabolite Laboratories, a case involving a patent claiming methods for testing homocysteine levels in a patient, and then using the 
homocysteine levels thus measured to diagnose that patient. Laboratory Corporation first licensed these methods from Metabolite Laboratories, but then discontinued paying royalties to Metabolite Laboratories after switching to an alternate test owned by Abbott Laboratories. When Metabolite Laboratories subsequently sued it for patent infringement, Laboratory Corporation countered by arguing that the patent claim - claim 13 - asserted against it was invalid because it impermissibly required a mental step. Claim 13 involved a "method for detecting a deficiency of cobalamin or folate” that included the step of "correlating an elevated level of total homocysteine in [a measured] body fluid with a deficiency of cobalamin or folate.” At trial, the inventors of claim 13 agreed that "correlating” referred to recognition of an elevated concentration of homocysteine by a physician, and "would occur automatically in the mind of any competent physician.” Both the district court and the CAFC found claim 13 valid. After accepting the appeal, the Supreme Court limited its inquiry to the following narrow question: "[w]hether a method patent ... directing a party simply to ‘correlate’ test results can validly claim a monopoly over a basic scientific relationship ... such that any doctor necessarily infringes the patent merely by thinking about the relationship after looking at a test result.” In a surprise to both litigants, the Court finally declined to decide the case, instead deciding that it had granted certiorari improvidently. Although the Court issued not decision on the merits of the case, Justice Stephen Breyer filed a vigorous dissent to the decision 
to dismiss the appeal, made it clear that he would have found claim 13 invalid for requiring a mental step.

The Supreme Court considered the patentability of claims having mental steps again in 2010, this time issuing a decision in Bilski v. Kappos. In this case, the claimed invention at issue involved a method of hedging risk in commodity trading. Both the Board of Patent Appeals and Interferences (an administrative court within the USPTO) and the CAFC held the claims at issue invalid. The Supreme Court found similarly, stating that "[t]he patent application here can be rejected under our precedents on the unpatentability of abstract ideas.”

In 2011, the Supreme Court agreed to hear Mayo v. Prometheus, an appeal whose central issue concerned the patentability of methods of diagnosis and therapy. The claims at issue involved three principle steps: (1) administration of thiopurine to a patient, (2) measurement of thiopurine in the patient, and (3) calibration of drug dosage to be administered to the patient based on the measured amount of thiopurine. The district court had held these claims to be unpatentable, while the CAFC reversed in 2010, finding the claims patentable.

Just one day after deciding Bilski v. Kappos, the Supreme Court ordered the CAFC to reconsider its decision in light of the former court's decision in Bilski v. Kappos. Upon reconsideration, the CAFC came to the same decision it had before, this time justifying its result on the Bilski v. Kappos decision. Subsequently, the Supreme Court granted certiorari to hear an appeal of Mayo v. 
Prometheus. On March 20, 2012, the Supreme Court unanimously reversed the CAFC, holding that methods of using human metabolites in diagnosis and therapy did not qualify as patentable subject matter. This decision also effectively reversed the CAFC's recent decision in Classen Immunotherapies v. Biogen IDEC, a 2011 decision that upheld the validity of several claims to methods of evaluating and improving the safety of immunization schedules. Justice Breyer's dissent in Laboratory Corporation of America Holdings v. Metabolite Laboratories in 2006 turned out to be a harbinger that the Supreme Court was on the verge of establishing a new and unforgiving rule against the patentability of methods of human diagnosis and treatment - a rule that accords with the wider trend against the patentability of human-related inventions. More recently, on June 19, 2014, the Supreme Court's decision in Alice v. CLS Bank International further reinforced this trend.

\subsection{Discussion and Conclusions}

\subsubsection{A Patent-Safe Harbor for Human-Related Innovation}

It is too early to know precisely what scope of inventions Section 33 will exclude from patentabilty. Oddly for an issue as controversial as human experimentation, the AIA was not accompanied by any formal legislative history useful in interpreting what sorts of inventions Congress and the President intended Section 
33 to cover. The phrase "directed to or encompassing a human organism" is vague on its face, and, although some of the words it contains are suggestive of language sometimes employed among patent attorneys, even this usage usually depends upon specific context to choose between alternative interpretations. Patent attorneys sometimes use the phrase "directed to" to indicate the core of a claimed invention, so "directed to ... a human organism" could suggest that a claimed invention is essentially a human being per se. On the other hand, "directed to" could be interpreted to refer to an invention having a close connection to a human organism; human genes, hESCs, products of in vivo conversion, or thoughts might satisfy this criterion. The word "encompassing" is similar in meaning to "open transition phrases," such as “comprising” or "including,” that link the introductory phrase of a claim with the specific elements recited by the claim. In this sense, its meaning implies that an invention would include an element (in this case, "a human organism”) without excluding other elements from the invention. Under this interpretation, “encompassing a human organism” could mean any invention that includes, as one of its constituent elements, a human; here, methods of in vivo conversion or inventions including mental steps, such as methods of diagnosis or treatment of a human, might satisfy this interpretation. Without interpretive legislative history, the meaning of Section 33 will have to found elsewhere in the law. 
Unless Congress decides to amend it, clarification of Section 33 will only arrive in the form of the regulations and rules promulgated by the USPTO and judicial decisions delivered by the federal courts. In the meantime, valuable guidance is available in the form of judicial decisions concerning the patentability of human-related inventions, notably human genes, hESCs, products of in vivo conversion, and thought. The 2012 Supreme Court decision, Mayo v. Prometheus, and its 2013 decision, AMP v. Myriad, exemplify this trend away from patent-eligibility for human-related inventions. Courts have not been indulgent when asked to enforce, find infringement of, or uphold the validity of human-related patents, suggesting that patent protection for such inventions is already generally weak at common law. The effect of Section 33 will probably be to undermine even further patent protection for human-related patents. Consistent with previous judicial decisions concerning patents claiming human-related inventions, such as Mayo v. Prometheus and AMP v. Myriad, Section 33 will likely prohibit not only those patents that claim human beings per se, but also emanate a wider penumbra of prohibition that excludes that patenting of other human-related inventions. This penumbra will likely include human genes, embryonic stem cells, products of in vivo conversion, thoughts, and other types of biotechnological inventions having close connections to "a human organism."

The patent-safe harbor Section 33 creates within biotechnology formalizes a trend in U.S. patent law, but also brings U.S. patent law into closer accord with 
the treatment of biotechnological inventions in European patent law. As noted above, the European Patent Convention and the European Union have both established formal legal limitations on human-related inventions, notably human genes, hESCs, thought, and methods of medical treatment and diagnosis. As in Europe, U.S. patent law now formally recognizes a lacuna of unpatentable subject matter within biotechnology.

\subsubsection{A Natural Experiment on Innovation without Patents}

Section 33 now offers a valuable opportunity to observe a natural experiment on how innovation behaves when patent protection is formally removed.

Biotechnology has operated within the context of robust patent protection since the Supreme Court decision in Diamond v. Chakrabarty. Moreover, the biotechnology industry has long depended on the availability of patents to attract the investment necessary to justify large expenditures on research, development, and securing required federal regulatory approvals (Jasanoff 2005). If the successes of open and user innovation reported for fields outside biotechnology translate into biotechnology, and, if patents hamper such innovation, then a patent-safe harbor could spur increased innovation in human-related biotechnology. The natural experiment in innovation made possible by Section 33 offers the possibility of falsifying the innovation-needs-patents assumption that 
pervades biotechnology, and, if so, identify a new set of conditions in which patent protection does not support innovation.

\subsubsection{Human-Related Inventions as a Charter Technology}

A patent-safe harbor may play a role in innovation analogous to the role that has been proposed for “charter cities.” Paul Romer (2010) has suggested that special reform zones, called charter cities, might serve salutary purposes, such as fostering good governance practices, ensuring liberty for citizens, and encouraging economic prosperity. His proposal imagines that any country wishing to improve its governance and economy could set aside vacant land large enough for a city, import, establish, and enforce a set of rules already proven to promote good governance, and then invite any people who agree to abide by these rules to immigrate voluntarily. By supporting trustworthy laws and prosperity-supporting institutions in one geographically-circumscribed region of country otherwise plagued by untrustworthy laws and failing institutions, a charter city would allow its host country to run an experiment that compared new and old - and, perhaps, good and poor - governance. If the charter city produced desirable results, it could then provide a model for how to reform the laws and institutions of its host country. On the other hand, if the charter city were to underperform, or perform no better than, its host country, this result would also be useful in avoiding undesirable or detrimental reforms. 
Section 33 may play a role analogous to a charter city, with human-related biotechnological inventions representing a "charter technology" within the wider field of biotechnology. If innovation thrives disproportionately within this charter technology in the absence of patent protection, Congress could use such results as a model for how to improve innovation outcomes in other fields of technology. Patent-safe harbors could be introduced in other fields of technology, and innovation outcomes similarly monitored. If open and user innovation in humanrelated biotechnology were to thrive in the absence of patent rights, this would provide a strong argument to policy makers to reconsider the assumption that the patent system is the best policy tool with which to encourage technological innovation.

\subsubsection{A New Paradigm for Designing Innovation Policy}

Some critics of patent rights suggest that the rate and quality of technological innovation might increase sans patent protection (von Hippel 2005, Benkler 2006, Boldrin and Levine 2008). Section 33 may allow this proposition to be tested, at least with respect to a circumscribed field or research within biotechnology. The results of this experiment could influence future public policy by helping to guide the wise choice of legal instruments for promoting innovation. Without patent protection, innovation in human-related biotechnology may thrive, or it may not. Some fields of technological innovation may respond better than others to patent- 
free conditions. A decrease in the rate or quality of innovation in the absence of patent protection could even reinforce the current orthodoxy that patents best spur innovation. Regardless of the results of the experiment Section 33 has made possible, it is an experiment in technological innovation that is well worth conducting. It provides a rare opportunity to tip the balance of innovation policy away from patent protection and towards open and user innovation.

\section{References}

Benkler, Y. 2006. The wealth of networks: How social production transforms markets and freedom. New Haven, CT: Yale University Press.

Bessen, J., and M. Meurer. 2008. Patent failure: How judges, bureaucrats, and lawyers put innovators at risk. Princeton, NJ: Princeton University Press.

Boldrin, M., and D.K. Levine. 2008. Against intellectual monopoly. New York, NY: Cambridge University Press.

Burk, D.L., and M.A. Lemley. 2009. The patent crisis and how the courts can solve it. Chicago, IL: The University of Chicago Press.

Crease, D., and G. Schlich. 2003. “Is There a Future for 'Speculative’ Gene Patents in Europe?” Nature Reviews Drug Discovery 2 (5): 407-410. Crichton, M. 2007. “Patenting Life.” New York Times 2007, Feb. 13: A2. Goodwin, M. 2006. Black markets: The supply and demand of body parts. New York, NY: Cambridge University Press. 
Heller, M.A., and R.S. Eisenberg. 1998. “Can Patents Deter Innovation? The Anticommons in Biomedical Research.” Science 280 (no. 5364): 698-701. Hollon, T. 2000. “Gene Patent Revisions to Remove Some Controversies.” Nature Medicine 6 (4): 362-363.

Jaffe, A.B., and J. Lerner. 2006. Innovation and its Discontents: How our Broken Patent System is Endangering Innovation and Progress, and what to do About it. Princeton, NJ: Princeton University Press.

Jasanoff, S. 2005. Designs on Nature. Princeton, NJ: Princeton University Press. Jensen, K., and F. Murray. 2005. "Intellectual Property Landscape of the Human Genome.” Science 310 (no. 5746): 239-240.

Madoff, R.D. 2010. Immortality and the Law - The Rising Power of the American Dead. New Haven, CT: Yale University Press.

Moser, P. 2005. “How Do Patent Laws Influence Innovation? Evidence from Nineteenth-Century World Fairs.” The American Economic Review 95 (4): 12151236.

Purves, D., E.M. Brannon, R. Cabeza, S.A. Huettel, K.S. LaBar, M.L. Platt, and M. Woldorff. 2008. Principles of Cognitive Neuroscience. Sunderland, MA: Sinauer Associates.

Rao, R. 2007. “Genes and Spleens: Property, Contract, or Privacy Rights in the Human Body?” Journal of Law, Medicine \& Ethics 35 (3): 371-382. 
Rimmer, M. 2008. Intellectual Property and Biotechnology - Biological Inventions. Cheltenham, UK: Edward Elgar Publishing. Romer, P., and B. Fuller. 2010. “Cities from Scratch: A New Path for Development.” City Journal 20 (4).

Silverman, R.B. 2004. The Organic Chemistry of Drug Design and Drug Action. Second edition. Burlington, MA: Elsevier Academic Press.

Strandburg, K.J. 2008. "Users as Innovators: Implications for Patent Doctrine.” University of Colorado Law Review 79 (46): 467-544.

Torrance, A.W. 2007. "Patents to the Rescue - Disasters and Patent Law.” DePaul Journal of Health Care Law 10 (3): 309-358.

Torrance, A.W. 2008. “Physiological Steps Doctrine.” Berkeley Technology Law Journal 23 (4): 1471-1505.

Torrance, A.W. 2009. “Neurobiology and Patenting Thought.” IDEA: The Journal of Law and Technology 50: 27-58.

Torrance, A.W., and W.M. Tomlinson. 2009. "Patents and the Regress of Useful Arts.” Columbia Science and Technology Law Review 10: 130-168.

Torrance, A.W. 2010a. "Gene Concepts, Gene Talk, and Gene Patents.” Minnesota Journal of Law, Science \& Technology 11 (1): 157-191. Torrance, A.W. 2010b. "Synthesizing Law for Synthetic Biology.” Minnesota Journal of Law, Science \& Technology 11 (2): 629-664. 
Torrance, A.W. 2011. "Property Rules, Liability Rules, and Patents: One Experimental View of the Cathedral.” Yale Journal of Law \& Technology, 14 (1): 138-161.

Torrance, A.W. 2013. “The Unpatentable Human Being.” Hastings Center Report 43 (5): 10-11.

Torrance, A.W., and L.J. Kahl. 2014. “Bringing Standards to Life: Synthetic Biology Standards and Intellectual Property.” Santa Clara High Technology Law Journal 30(2): 199-230.

Von Hippel, E. 2005. Democratizing Innovation. Cambridge, MA: MIT Press. 